\title{
喉頭乳頭腫に対する特殊治療
}

\section{室野重之・吉崎智一 \\ Advanced Treatment for Recurrent Laryngeal Papillomatosis}

\section{Shigeyuki Murono and Tomokazu Yoshizaki}

\begin{abstract}
Cidofovir is an anti-viral agent and has been anticipated to eradicate human papillomavirus in cases of recurrent respiratory papillomatosis (RRP). We herein summarize four new cases of more severe RRP than have been previously reported, which were treated with intralesional injection of the agent. Three of the four cases achieved minimal residual disease. However, recurrence of the disease was observed in all three cases, and further surgical intervention with intralesional injection of the agent was attempted. The remaining case had very severe disease requiring reduction of the tumor volume at the initial injection. Repeated recurrence required further surgical interventions with intralesional injection of the agent. The trends in Europe and the United States of America, as seen in statements approved by the RRP Task Force, should be considered when performing the treatment.
\end{abstract}

Key words : recurrent laryngeal papillomatosis, cidofovir, human papillomavirus

\section{は じめ に}

喉頭乳頭腫の治療は $\mathrm{CO}_{2}$ レーザーやマイクロデブリッ ダーを用いた手術が一般的であるが, 再発しやすいため治 療に難渋することも少なくない. その対策として，イン ターフェロン $\alpha$ やアシクロビル, 漢方薬を用いた補助療法 が報告されているが，治療成績は決して満足のいくもので はない ${ }^{1 \sim 3)}$ 。本疾患はヒト乳頭腫ウイルス (human papillomavirus, HPV) の 6 型 (HPV-6) および 11 型 (HPV11）の関与が示唆されているため, 欧米では抗ウイルス作 用を有する核酸類似体であるシドフォビルの局所注入治療 の有効性が報告されてきた ${ }^{4,5)}$. 当科でも今までに 5 例に 対して同治療を施行し, 数回にわたって報告してきた ${ }^{6 \sim 8)}$. 今回, さらに, より高度な症例を経験したので概要を報告 し, 欧米における現状について文献的に考察するととも に,アンケートにより本邦における本治療の現状を調査し たのであわせて報告する.

\section{対象と方 法}

2007 年から 2012 年までを対象とした先の報告の 5 例以 降の 4 例を対象とした。これらの 4 例はいずれも，先の報 告の 5 例よりも病変が高度であった。全例, 当院 Institutional Review Boardでの承認を経た後に, 本治療法 の十分な説明を行い，書面による同意を取得した。長期間 にわたり数多くの治療成績を発表しているNaimanらの方 法に準じて，過去の報告と同様に施行した ${ }^{8,9)}$ 。具体的に は，全身麻酔下の喉頭直達鏡によるシドフォビル注入を 2
週ごとに 3 回施行することとし, シドフォビルの濃度は $7.5 \mathrm{mg} / \mathrm{ml}, 1$ 回あたりの注入量は病変の程度に応じて 2 $5 \mathrm{ml}$ とした。治療効果は，喉頭内視鏡所見により，腫瘍を 確認できなくなったものを「消失」，腫瘍の完全消失に至 らないがほぼわからなくなったものを「著明改善」，腫瘍 は縮小したが明らかに残存しているものを「改善」，腫瘍 の縮小を認めないものを「不変」，として評価した。

また，本邦におけるシドフォビル局所注入治療の現状を 評価するためにアンケートを施行した。（1）シドフォビル 局所注入治療の経験の有無，（2）有の場合の施行症例数, （3）シドフォビル静脈投与治療の経験の有無，を質問項目 とし，全国の医育機関病院（分院がある場合には本院のみ） の 80 施設へ郵送し，ファックスにより回答を得た.

\section{症 例 の 提 示}

症例 1

29 歳女性。両声帯に多発する病変を認めた。著明改善 を認めたが 2 か月後に再燃し，現在，施行前と同様の状態 である。ママイクロデブリッダーによる切除とアジュバント としてのシドフォビル局所注入治療を予定している. 症例 2

44 歳男性. 喉頭蓋喉頭面, 両仮声帯, 両声帯に多発す る病変を認めた。改善を認めたが 2 か月後に再燃し, マイ クロデブリッダーによる切除術とアジュバントとしてのシ ドフォビル注入術を施行し，経過観察中である. 症例 3

48 歳男性. 喉頭蓋喉頭面, 両仮声帯, 両声帯, 両披裂 
部にきわめて高度の病変を認めた（図 $1 \mathrm{~A})$ ，本例では減 量が不可避であったため, 3 回のシドフォビル注入時には マイクロデブリッダーによる切除術を先行した。施行後 2 か月で再発を認め, マイクロデブリッダーによる切除とア ジュバントとしてのシドフォビル局所注入による追加治療 を 2 回（計 5 回）施行し, 経過観察中である（図 1 B, C). 症例 4

69 歳男性. 両声帯に多発する病変を認めた。改善を認 めたが 2 か月後に再燃し，現在，施行前と同様の状態であ る. マイクロデブリッダーによる切除とアジュバントとし てのシドフォビル局所注入治療を予定している。

$$
\text { アンケートの結果 }
$$

57 大学 $(71 \%)$ より回答を得た。シドフォビル局所注入 治療の施行経験は 7 大学 $(12.3 \%)$ であった。最も多くの 症例を経験している施設では 11 例，最も少ない施設では 1 例であり, 合計 27 例であった。 これらののべ手術回数 は 84 回であった。一方, シドフォビルの静脈投与治療を 施行している施設はなかった。

\section{考察}

シドフォビルは核酸類似体 (ヌクレオチドアナログ) で あり，デオキシシチジン 1 リン酸 $(\mathrm{dCMP})$ と類似の構造 を有している ${ }^{10)}$ 。dCMP は宿主リン酸化酵素によりさら に二リン酸化され，デオキシシチジン 3 リン酸 $(\mathrm{dCTP})$ と なりDNA合成時に利用され，以降さらにDNAが伸張し ていく，一方，シドフォビルもリン酸基を 1 つ有して扔り， 同様に宿主リン酸化酵素によりさらに二リン酸化される と， dCTP同様にDNA合成時に利用されるが，以降の DNA 伸張は阻害される ${ }^{10)}$ ，そのためサイトメガロウイル ス $(\mathrm{CMV})$, エプスタインーバールウイルス $(\mathrm{EBV})$ など のヘルペスウイルス族に加え，HPVにも抗ウイルス作用 を有している ${ }^{10)}$ 。臨床的にはアメリカ食品医薬品局 （FDA）による承認は後天性免疫不全症候群患者に扔ける $\mathrm{CMV}$ 網膜症のみであるが，HPV関連腫瘍である喉頭乳頭 腫での有効性が報告されてきた ${ }^{5}$.

喉頭乳頭腫に対するシドフォビル注入に扔ける至適投与 量や方法についてはエビデンスがなく，各施設の成績が報 告されているのみである。これら 17 論文 158 症例のレ ビューでは，消失 $58 \%$ （90 例）, 有効 35\%（55 例）, 無効 $8 \%$ （13 例）の結果である ${ }^{5)}$. また，シドフォビルの濃度 は大半が $2.5 \sim 7.5 \mathrm{mg} / \mathrm{mL}$ であり, 平均注入回数は 7 回 (1 〜22 回) であること, 注入間隔は大半が $2 \sim 4$ 週であり， 平均治療期間は 11 か月（1～54 か月）であることが報告 されている。また， 51 論文 504 例をまとめた最近の報告 でも，シドフォビルの濃度は $76 \%$ の報告において 5 $7.5 \mathrm{mg} / \mathrm{mL}$ であり, 1 回注入量は $76 \%$ の論文で $5 \mathrm{~mL}$ 以下， 平均注入回数は 8.1 回とされている ${ }^{11)}$. 一方, シドフォビ ルの投与の有無で比較した報告はわずかに 2 つ認めるのみ である ${ }^{12,13)}$.1つはわずか 19 例におけるランダム化試験
A

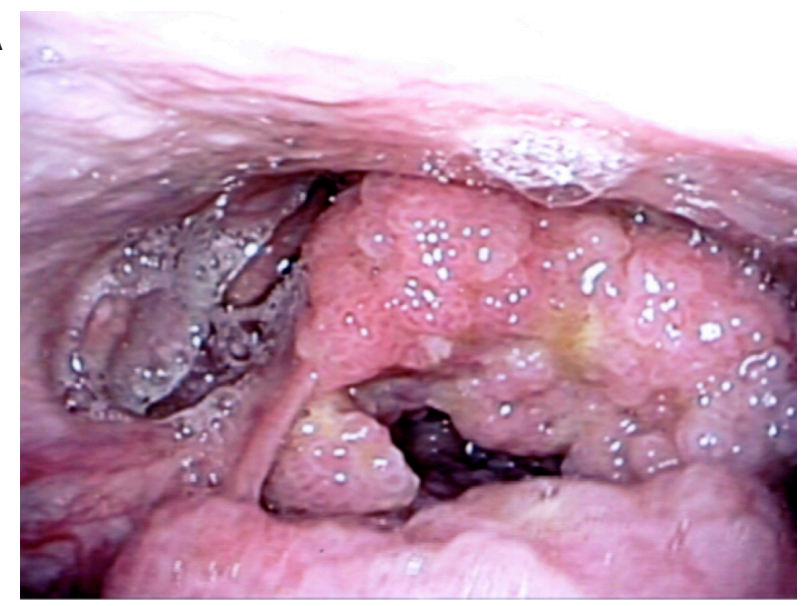

B

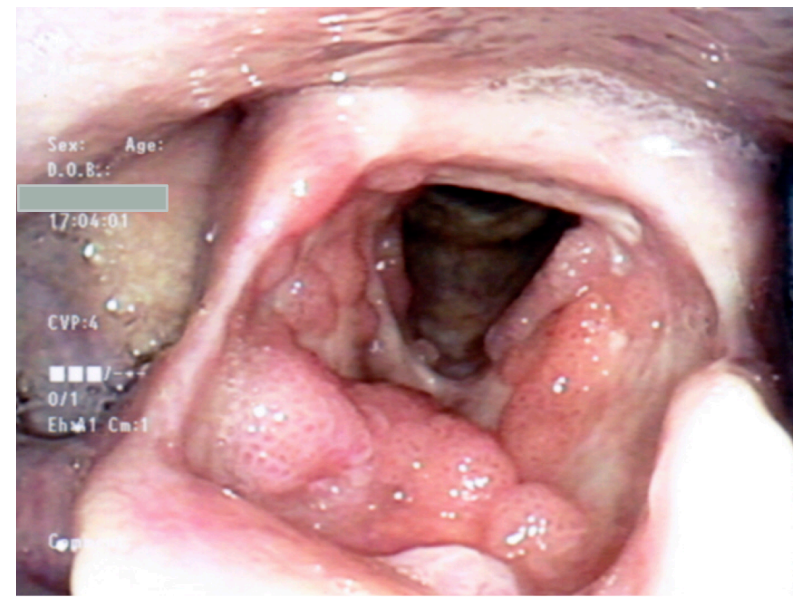

C

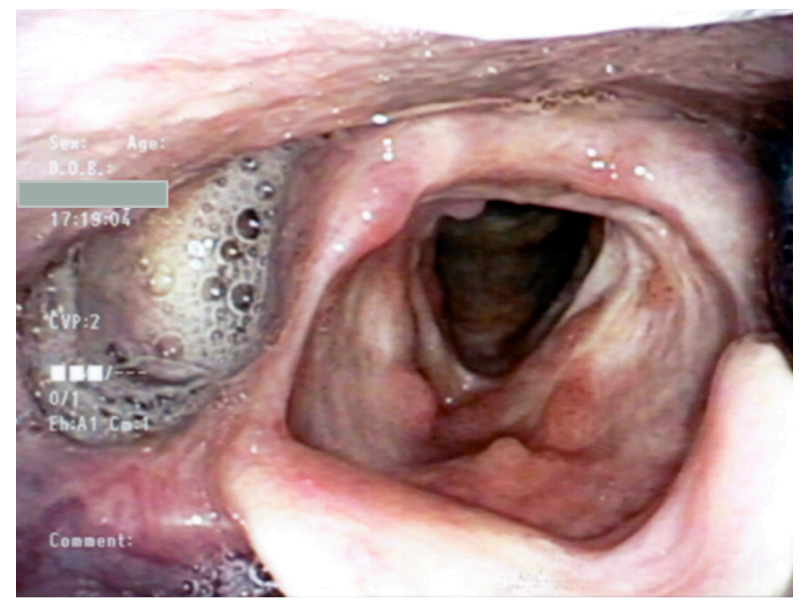

図 1 症例 3 の喉頭内視鏡所見.

(A) 治療前には広く喉頭に高度の乳頭腫を認める。 (B) 4 回目治療終了後 2 か月では乳頭腫は軽快するも 再燃が明らかである。 (C) 5 回目治療終了後 2 か月で は乳頭腫の軽度の再燃を認める。

で，切除後にシドフォビルもしくはプラセボ薬を局所注入 しているが，乳頭腫の重症度を示す Derkay スコア ${ }^{14)}$ の改 善は両群間に有意差は認めていない ${ }^{12)}$ 。しかしこの報告 では，シドフォビルの濃度が 1 例では $0.3 \mathrm{mg} / \mathrm{mL} ， 6$ 例で 
は $0.75 \mathrm{mg} / \mathrm{mL}, 3$ 例では $5.0 \mathrm{mg} / \mathrm{mL}$ あ゙あり, 低いもの が大半となって㧍り，その影響も否定できない。もう 1 つもわずか 7 例での症例対照試験で, 減量後に $5 \mathrm{mg} / \mathrm{mL}$ のシドフォビルを注入し, 薬剤投与群では対照群より Derkay スコアが有意に改善していることが報告されてい る ${ }^{13)}$.

シドフォビルの使用に際して最も問題となる有害事象 は腎障害と発癌性である。シドフォビル局所投与による pharmacokinetic studyでは, 当該量の静脈投与に比べて 血中濃度が低いことが示されている。また， $1 \mathrm{mg} / \mathrm{kg}$ での 静脈投与では腎障害をきたすことはほとんどないとされ ており，今回の症例ではいずれも 1 回あたりの投与量は これを下回っている。発癌性の問題はラットに扔いて指 摘されたが，これまでの報告ではヒトにおいてシドフォ ビルが原因と考えられる癌の発生の報告はない. Broekema らは188例のレビューにより，5例（2.7\%）に おいて治療中もしくは治療後に異形成を認めているが, これは $2 \sim 3 \%$ といわれる異形成の自然発生率と同等であ ることから, 発癌性は問題にならないと結論している ${ }^{15)}$.

しかし, 本薬剤の発売元であるGilead Science社は, 有 害事象を考慮して, 適応外使用を推奨しないパブリック コメントを出している ${ }^{16)}$. Off-label使用に関するこの声 明への反応として, European Laryngological Society (ELS) では, 多国間の多施設大規模後向き研究を施行し, シドフォビルを用いて治療された 275 例について, 腎障 害, 好中球減少，悪性転化，のいずれに抒いてもシドフォ ビル非使用群に比べて増加はないと報告した ${ }^{17)}$ 。また, 米国では, Recurrent Respiratory Papillomatosis夕スク フォースによる18の声明が発表され，2〜3か月ごとに 減量が必要な症例に, $3 \mathrm{mg} / \mathrm{kg}$ を超えないように, アジュ バントとして使用する，などの適応や，インフォームド . コンセントが重要であるとする注意点などを喚起してい る $^{18)}$.

今回治療を施行した 4 例のうち 3 例では, 従来の注入 のみのプロトコールでは著明改善もしくは改善の後に再 燃を認め, 後にマイクロデブリッダーによる切除とアジュ バントとしてのシドフォビル局所注入治療を考虑した。 また，高度病変であった 1 例では当初からマイクロデブ リッダーによる切除も不可避であった。これらの結果は, シドフォビル局所注入治療は，より高度な病変抒いては 外科手技に加えるアジュバントとして位置づけられるこ とを示唆して拈り，米国のタスクフォースによる声明に 矛盾しないものである。今回施行したアンケートによる 調査では，本治療は本邦でも広まりつつあり，積極的に 取り組む施設も見られている。しかし，欧米での現況を 考慮すると，本治療がなし崩し的に拡散することは好ま しくない，米国でのタスクフォースの声明に見られる， 慎重な適応決定とじゅうぶんなインフォームド・コンセ ントが不可避であるとともに，ELSの反応に見られるよ うな組織だったプロジェクトも考慮する必要がある。

\section{ま と め}

再発性喉頭乳頭腫に対してシドフォビル局所注入を施 行した新たな 4 例についての概要を報告した。また，本 邦での現況についてアンケートにより調査し, 報告した. 欧米では学会やタスクフォースが主体となって本治療の 正当性を確立しょうとして扔り，本邦に扔いてもこれら の動向に注意していく必要がある。

\section{謝辞}

アンケートにご協力賜りました皆様に深謝いたします。

利益相反に該当する事項はない.

\section{参 考 文献}

1) Xiao M, Wang $C$, Zhang J et al : IFN gamma promotes papilloma development by up-regulating Th17associated inflammation. Cancer Res 69 : 2010-2017, 2009.

2) Gallagher TQ, Derkay CS : Pharmacotherapy of recurrent respiratory papillomatosis : an expert opinion. Expert Opin Pharmacother 10 : 645-655, 2009.

3) Okubo K, Saito K, Fukuda H et al : Traditional Chinese Medicine for treatment of laryngeal papillomatosis. J Altern Complement Med 16 : 427 - 433, 2010.

4) Snoeck R, Wellens W, Desloovere C et al : Treatment of severe laryngeal papillomatosis with intralesional injections of cidofovir [ (S) -1- (3-hydroxy-2-phosphonyl-methoxyproply) cytosine]. J Med Virol 54 : 219225, 1998.

5) Chadha NK, James AL: Antiviral agents for the treatment of recurrent respiratory papillomatosis: a systematic review of the English-language literature. Otolaryngol Head Neck Surg 136 : 863-869, 2007.

6）吉崎智一, 辻 亮, 室野重之: 再発性喉頭乳頭腫に 対するシドフォビル治療。日気食会報 $60: 344-347$ ， 2009.

7）吉崎智一, 室野重之：シドフォビルによる再発性读 頭乳頭腫治療。喉頭 22:124-127, 2010.

8）室野重之, 吉崎智一：喉頭乳頭腫に対するシドフォ ビル治療。喉頭 $24: 70-73,2012$.

9) Naiman N, Abedipour D, Ayari S et al : Natural history of adult-onset laryngeal papillomatosis following multiple cidofovir injections. Ann Otol Rhinol Laryngol 115 : 175-181, 2006.

10) De Clercq E : Antivirals for the treatment of herpesvirus infections. J Antimicrob Chemother 32 Supple A : 121-132, 1993.

11) Clamp PJ, Saunders MW : Systematic review of int- 
ralesional Cidofovir dosing regimens in the treatment of recurrent respiratory papillomatosis. Int J Periatr Otorhinolaryngol 77 : 323-328, 2013.

12) McMurray JS, Connor N, Ford CN : Cidofovir efficacy in recurrent respiratory papillomatosis : a randomized, double-blind, placebo-controlled study. Ann Otol Rhinol Laryngol 117 : 477-483, 2008.

13) Mandell DL, Arjmand EM, Kay DJ et al : Intralesional cidofovir for pediatric recurrent respiratory papillomatosis. Arch Otolaryngol Head Neck Surg 130 : 1319-1323, 2004.

14) Derkay CS, Malis DJ, Zalzal G et al : A staging system for assessing severity of disease and response to therapy in recurrent respiratory papillomatosis. Laryngoscope 108 : 935-937, 1998.

15) Broekema FI, Dikkers FG : Side-effects of cidofovir in the treatment of recurrent respiratory papillomatosis. Eur Arch Otorhinolaryngol 265 : 871-879, 2008
16) Gillen D : Direct Healthcare Professional Communication regarding serious adverse reactions following off-label use of Vistide. http://www.cbg-meb.nl/NR/ rdonlyres/FFB 51936 -EC 22 - 4180 -A 213 9E907F 06 A 774/0/VistideDHPCletterJanuary 2011. pdf

17) Tjon Pian Gi RE, Ilmarinen T, van den Heuvel ER et al : Safety of intralesional cidofovir in patients with recurrent respiratory papillomatosis: an international retrospective study on 635 RRP patients. Eur Arch Otorhinolaryngol 270 : 1670-1687, 2013.

18) Derkay CS, Volsky OG, Rosen CA et al : Current use of intralesional cidofovir for recurrent respiratory papillomatosis. Laryngoscope 123 : 750-712, 2013.

\section{別刷請求先 广 920-8640 石川県金沢市宝町 13-1} 金沢大学耳鼻咽喉科 $\cdot$ 頭頸部外科 